Bernadet is pedicure. Zij deelt haar praktijkervaringen - met een kwinkslag en in de overtreffende trap - middels deze column in Podopost en een blog in de nieuwsbrief. Daarbij ventileert zij haar ongezouten visie op zaken binnen de pedicurewereld.

\title{
Half leeg of half vol?
}

\section{6 oepie, we hebben maar liefst drie weken vakantie voor de boeg! De kampeerspullen zitten in de auto gepropt, morgenochtend vertrekken} we. Om 5 uur 's ochtends starten we onze bolide. De motor slaat aan, zegt plof en gaat meteen weer uit. Ik probeer nog een paar keer, maar nee, de auto heeft absoluut geen zin in dit reisje. We hebben geen idee wat er scheelt. Wat nu? Het is zondag, we kunnen de garage pas morgen bellen. Nou ja, dan maar eerst een dagje vakantie in eigen tuin vieren. Er zit niets anders op. Op maandagmorgen hangen we stipt om 8 uur met de garagehouder aan de telefoon. Hij belooft dat de monteur aan het eind van de middag komt kijken. Nee, eerder lukt niet: "sorry, geen tijd". Mmmm, dan maar koffie drinken, verzuchten we. Binnen, want de regen valt inmiddels met bakken uit de hemel. De diagnose van de monteur is niet mals: "Er is iets ernstig kapot. Jullie mogen van geluk spreken dat dit niet onderweg is gebeurd. Het goede nieuws: het is te repareren. Het slechte nieuws: het te bestellen onderdeel arriveert op z'n vroegst woensdag. Ik zet de reparatie voor donderdag op de planning." Donderdag?? Maar dan kunnen we pas vrijdag vertrekken!

Ik baal als een stekker. Al wekenlang verheug ik me op deze vakantie. Ik heb me het apelazarus gewerkt om alle voeten van tevoren in orde te krijgen. In plaats van lekker aan het strand liggen, boekjes lezen en flaneren over boulevards, zit ik nu binnen op de bank tegen de Hollandse motregen aan te kijken. Er blijven nog hooguit twee weken over voor de Cote d'Azur, bedenk ik sip! Lief baalt natuurlijk ook, dus kibbelen we over niets. Ik voel de gedroomde vakantie tussen mijn vingers door glippen. Omgaan met teleurstellingen, da's niet gemakkelijk. Dat geldt natuurlijk precies eender voor de tegenslagen in de praktijk. Het zoveelste apparaat dat kapot gaat, tegenvallende inkomsten, cliënten die niet komen opdagen, vervelende brieven van de belastingdienst. Toch maakt het veel uit hoe je hiermee om weet te gaan. Is het glas half leeg of half vol? Omdenken noemen we dat. Als we ons realiseren dat de zon inmiddels allang weer schijnt, bedenken we dat de keus aan ons is: de eerste vakantieweek in het water

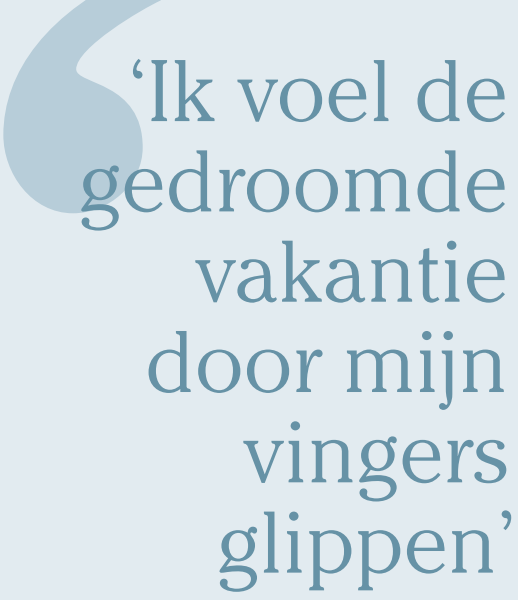

laten vallen óf proberen er wat van te bakken. We kiezen eieren voor ons geld. De daaropvolgende dagen brengen we lekker lui lezend door. Het restaurantje om de hoek mag voor ons koken. We zijn nog nooit zo fijn uitgerust op vakantie vertrokken. Meer weten? www.omdenken.nl 